Jurnal ABDINUS : Jurnal Pengabdian Nusantara, 3 (1), 2019, 30-35

Available online at: http://ojs.unpkediri.ac.id/index.php/PPM

DOI: $\underline{\text { https://doi.org/10.29407/ja.v3i1.13512 }}$

\title{
Penerapan Analisis Regresi Linier Berganda dalam Penyelesaian Skripsi Mahasiswa
}

\author{
Aryo Wibisono ${ }^{*}$,Mohammad Rofik ${ }^{2}$, Edy Purwanto ${ }^{3}$ \\ 1aryo.wibisono45@gmail.com \\ 1,2,3 Manajemen \\ ${ }^{1,2,3}$ Fakultas Ekonomi dan Bisnis \\ ${ }^{1,2,3}$ Universitas Wiraraja
}

Received: 0808 2019. Revised: 0908 2019. Accepted: 28082019

\begin{abstract}
Students often experience problems in choosing the method of completing their thesis, as a result, student thesis planning is hampered. During lectures, they only know the theory and practice of statistics without practicing in depth. Therefore this dedication is carried out to assist a group of students in determining the method that suits their thesis. The formulation of the problem is due to the lack of understanding for students in choosing analytical tools to conduct their research. As well as adding insight in doing descriptive statistical analysis and multiple linear regression. The purpose of this training is to add insight in analyzing using the SPSS software. The target in this service is the final year students who are taking thesis which is held in June 2019. This training will later use the SPSS software as an analytical material in conducting thesis. From the results of monitoring during the assistance in this service, the majority of participants with a percentage of $84 \%$ who can complete 5 cases with a perfect score of 100 , another $16 \%$ get a score of 70 . And from these results are in accordance with the training target, as well as many of the participants who expressed satisfaction with the training that was held.
\end{abstract}

Keywords: SPSS, Multiple Linear Regression, Students

\begin{abstract}
Abstrak: Mahasiswa sering mengalami permasalahan dalam pemilihan metode penyelesaian skripsinya, akibatnya perencanaan skripsi mahasiswa menjadi terhambat. Pada saat perkuliahan, mereka hanya mengenal teori dan latihan statistika tanpa mempraktikan secara mendalam. Oleh karena itu pengabdian ini dilaksanakan untuk mendampingi sekelompok mahasiswa dalam menentukan metode yang sesuai dengan skripsi mereka. Perumusan masalahnya karena kurangnya pemahaman bagi mahasiswa dalam memilih alat analisis untuk melakukan pelatihannya. Serta penambahan wawasan dalam melakukan analisis statistik deskriptif dan regresi linier berganda. Adapun tujuan terlaksananya pelatihan ini adalah dalam rangka penambahan wawasan dalam melakukan analisis dengan menggunakan software spss. Sasaran dalam pengabdian ini adalah mahasiswa tingkat akhir yang sedang menempuh skripsi yang dilaksanakan pada bulan Juni 2019. Pelatihan ini nantinya akan menggunakan software SPSS sebagai bahan analisis dalam melakukan skripsi. Dari hasil monitoring selama pendampingan dalam pengabdian ini, mayoritas peserta dengan presentase $84 \%$ yang dapat menyelesaikan 5 kasus dengan nilai sempurna yaitu 100 , lainnya $16 \%$ mendapatkan nilai 70 . Dan dari hasil ini sudah sesuai dengan


target pelatihannya, serta banyak dari peserta yang menyatakan puas dengan pelatihan yang diadakan.

Kata kunci: SPSS, Regresi Linier Berganda, Mahasiswa

\section{ANALISIS SITUASI}

Skripsi merupakan suatu kegiatan diakhir perkuliahan yang mempunyai tujuan supaya mahasiswa mampu menyusun dan menulis suatu skripsi, sesuai dengan bidang ilmunya. Dimana mahasiswa dianggap mampu menuliskan skripsi dianggap mampu mensinkronkan antara pengetahuan serta keterampilannya dalam memahami, menganalisis, menggambarkan, serta menjelaskan masalah yang berhubungan dengan bidang keilmuan yang diambilnya. Skripsi merupakan persyaratan untuk mendapatkan status sarjana (S1) di setiap Perguruan Tinggi Negeri (PTN) maupun Perguruan Tinggi Swasta (PTS) yang ada di Indonesia. Permasalahan yang sering dialami oleh mahasiswa adalah bagaimana mereka memilih metode dalam menyelesaikan skripsinya, yang pada akhirnya akan menghambat mahasiswa dalam merencanakan skripsi mereka. Dan pada saat perkuliahan mereka hanya sebatas mengenal tentang teori - teori tanpa mempraktikan secara langsung. Sebelum melakukan pelatihan, maka sebaiknya yang perlu dilakukan adalah bagaimana cara menentukan latar belakang, tujuan, permasalahan, menentukan metode serta bagaimana cara mengelolah dan menganalisisnya. Karena masih ada beberapa mahasiswa yang belum memahami tentang hal tersebut, oleh karena itu diharapkan dengan adanya pelatihan ini nantinya dapat membantu dalam menambah wawasan bagi mahasiswa. Pelatihan ini nantinya akan menggunakan software SPSS sebagai bahan analisis dalam melakukan skripsi.

Regresi linier berganda sendiri menjelaskan tentang hubungan antar variabel, seperti variabel terikat dan variabel bebas. Variabel terikat di dalam analisis regresi sering juga disebut sebagai variable respon dan variable bebas sering disebut sebagai variabel prediktor. Variabel bebas adalah suatu besaran yang nilainya dapat ditentukan dari definisi yang diinginkan, variabel terikat adalah suatu besaran yang nilainya tergantung dari variabel bebas yang menjadi pasangannya. Misalkan kita sedang membicarakan masalah kinerja. Apa yang terkait dengan kinerja? tentunya ada kompensasi, kepemimpinan, motivasi, lingkungan kerja dan lain-lain. Kalau misalkan kita hanya ingin membicarakan masalah peningkatan kinerja, maka kinerja akan tergantung dari motivasi yang dilakukan, apabila motivasi sesuai sasaran dengan sendirinya kinerja akan meningkat. Jadi dalam permasalahan ini peningkatan kinerja disebut sebagai variabel respon dan motivasi sebagai variabel prediktor (Sujarweni, 2015 : 
32). Untuk mempermudah perhitungan dapat digunakan software Statistik yang dikenal dengan sebutan SPSS.

Memasuki masa skripsi, dimana setiap mahasiswa pasti akan melakukan pelatihan, oleh karena itu nantinya pelatihan yang diberikan menyesuaikan dengan kebutuhan mahasiswa dalam membuat skripsi. Dan diharapkan mahasiswa mampu mengelolah dan menganalisis dari hasil pelatihannya.

Dalam pelatihan ini nantinya akan difokuskan pada beberapa analisis yang berkaitan dengan kebutuhan dalam melakukan pengelolahan dan analisis data bagi mahasiswa sebagai berikut : analisis deskripsi merupakan analisis yang paling mendasar untuk menggambarkan keadaan data secara umum. Secara umum analisis deskripsi mencakup beberapa hal terkait sub menu deskriptif statistik seperti frekuensi, deskriptif, eksplorasi data, tabulasi silang dan analisis rasio. Dan untuk uji asumsi klasik sendiri untuk menguji tentang standart data sebelum dilakukan uji regresi linier berganda.

\section{SOLUSI DAN TARGET}

Dari permasalahan diatas, maka solusi yang ditawarkan adalah melakukan pelatihan analisis statitika regresi linier berganda untuk penulisan pada karya tulis ilmiah dengan menggunakan bantuan software SPSS (Basuki, 2016). Peserta yang mengikuti pelatihan analisis statistik merupakan rata - rata mahasiswa tingkat akhir. Dalam pelaksanaannya yang ditargetkan kuotanya 20 orang yang hadir. Tetapi yang hadir dalam pelatihannya melebihi dari kuota yaitu yang daftar 30 orang, melihat antusiasnya peserta, maka ditambahkan kuotanya menjadi 30 orang. Kerangka pemecahan permasalahan yang digunakan meliputi rangkaian sebagai berikut ini :

1. Pemaparan materi tentang uji validitas dan reliabilitas, uji asumsi klasik dan regresi linier berganda untuk meningkatkan pengetahuan mahasiswa tentang metode statistik regresi linier berganda.

2. Pemaparan tentang bagaimana penerapan uji regresi linier berganda dalam karya tulis ilmiah

3. Pelatihan analisis regresi linier berganda dengan menggunakan software spss.

4. Dan pada akhir kegiatan ini mahasiswa mencoba menyelesaikan soal yang diberikan untuk mengetahui seberapa paham mereka dari hasil pelatihan tersebut.

Untuk mencapai tujuan dari pelatihan ini maka menggunakan metode sebagai berikut :

1. Kegiatan yang pertama adalah pemaparan tentang peranan skripsi bagi mahasiswa. 
2. Kegiatan yang kedua adalah pemaparan tentang peranan statistika dalam skripsi.

3. Kegiatan yang selanjutnya adalah pendampingan terhadap mahasiswa dalam melakukan analisis dengan menggunakan software SPSS. Dalam kegiatan ini mahasiswa diberikan 5 kasus di selesaikan dengan menggunakan analisis statistika.

Sedangkan untuk penilaian dilakukan dalam dua tahap, yaitu persiapan, dan pelaksanaan pelatihan, yaitu :

1. Yang pertama tahap persiapan, sistem penilaian dilakukan terhadap kesiapan modul untuk peserta pelatihan, bahan presentasi, serta tersedianya sarana dan prasarana. Jika semua telah tersedia, maka sesuai dengan yang direncanakan, serta dapat dikatakan persiapan sudah baik atau memenuhi kelayakan. Yang selanjutnya yaitu tahap kedua pelaksanaan.

2. Yang kedua tahap pelaksanaan hal-hal yang akan dinilai terdapat dua kriteria. Yang pertama merupakan kriteria keberhasilan dari sisi penyelesaian kasus, kegiatan ini dapat dikatakan sesuai dengan target jika paling sedikit 70\% untuk setiap peserta yang mampu melakukan analisis data dari 5 kasus yang diberikan dengan menggunakan software SPSS dan dapat memberikan implementasi yang sesuai. Keberhasilan ini dilihat dari hasil penyelesaian kasus yang dikerjakan oleh peserta. Serta yang kedua adalah kriteria keberhasilan dari sisi kepuasan peserta yang dapat dilihat melalui penyebaran angket setelah pelatihan yang bertujuan untuk melihat seberapa puas peserta dalam mengikuti pelatihan ini.

\section{METODE PELAKSANAAN}

Kegiatan pengabdian terhadap masyarakat yang dilaksanakan hari selasa tanggal 18 juni 2019 mulai dari jam 08.00 sampai dengan jam 12.00 bertempat di ruang laboratorium komputer Universitas Wiraraja yang dihadiri oleh 30 peserta pelatihan.

\section{HASIL DAN LUARAN}

Pada sesi awal, pelatihan di mulai oleh salah satu anggota pengabdian serta langsung dilanjutkan dengan pemaparan tentang bagaimana cara menentukan metode statistik yang tepat dalam penulisan skripsi. Selanjutnya masuk pada materi tentang teori dari uji validitas, uji reliabilitas, asumsi klasik serta regresi linier berganda. Selama proses pemaparan tentang materi tersebut, pemateri didampingi oleh 2 mahasiswa yang memahami tentang materi tersebut. Mereka memiliki tugas untuk mendampingi peserta, salah satunya menginstal 
aplikasi spss tiap komputer selama proses berlangsung. Setelah penyampaian materi selesai, maka masuk pada tahapan praktik yaitu peserta langsung mempraktikan apa yang di jelaskan oleh pemateri, dan pada sesi ini, tugas dari 2 mahasiswa tersebut mendampingi para peserta yang nantinya pada proses praktik mengalami kesulitan. Sedangkan pada sesi terakhir yaitu evaluasi, para peserta diberikan waktu dua jam untuk mengerjakan kasus yang berbeda tiap pesertanya. Hasil dari evaluasi pelaksanaan pelatihan ini adalah adanya kriteria keberhasilan yang sudah ditetapkan. Yang diperhatikan dalam melihat keberhasilan dari para peserta pelatihan adalah bagaimana mereka menyelesaikan kasus yang diberikan, pada tiap kasus terdapat poin / nilai, jadi bisa dilihat pada tingkat keberhasilannya dari seberapa banyak mereka meyelesaikan kasusnya.

Dari hasil praktik para peserta, mayoritas mampu menyelesaikan tiap kasusnya ini didapatkan dari hasil yang sudah diselesaikan rata-rata mampu mengerjakan dari 5 kasus yang diberikan, tetapi ada 5 peserta dari 30 peserta yang belum mampu menuntaskan dari 5 kasusnya. Jadi hanya sekitar $16 \%$ yang mendapatkan nilai 70 dari 100 dan sisanya memperoleh nilai sempurna. Pemahaman teori dari regresi linier berganda telah memenuhi target yang diharapkan yaitu yang berhasil mencapai target ada sekitar 25 peserta atau sekitar $84 \%$ yang sudah memenuhi syarat untuk mendapatkan nilai sempurna (100) dan hanya sekitar $16 \%$ yang belum memenuhi syarat mendapatkan nilai sempurna (70). Artinya pelatihan yang dilakukan sudah memenuhi keberhasilan dalam meningkatkan pengetahuan peserta tentang analisis regresi linier berganda.

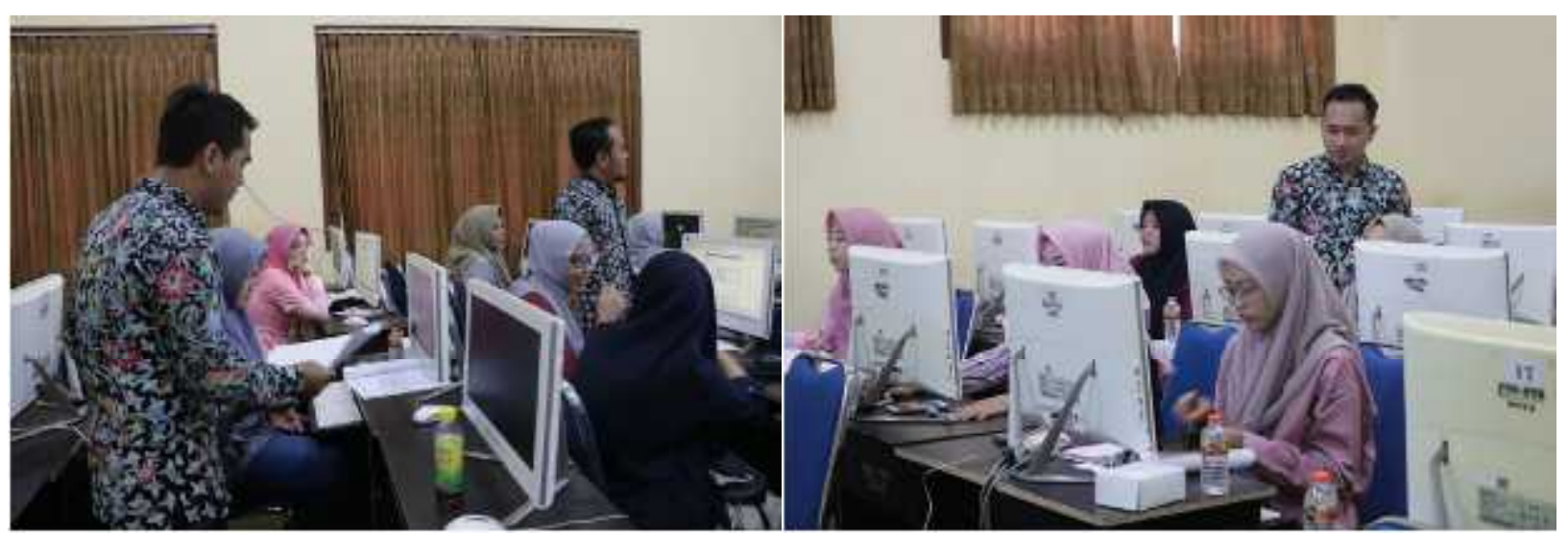

Gambar 1. Pendampingan Praktik

Gambar 2. Penjelasan Praktik

Selama pelatihan berlangsung, respon dari peserta sangat baik dan antusias karena menurut peserta pemateri cukup menarik dalam penyampaian materi, pemateri memberikan pemahaman yang intens bagi yang belum paham dan pemateri sabar dalam menghadapi peserta. Dan saran yang didapatkan selama pelatihan disebar melalui angket yang diisi oleh 
peserta pelatihan. Untuk angket no. 1 menanyakan tentang pendapat peserta mengenai materi pelatihan, dan sekitar 90,81\% menyatakan materi yang disampaikan menarik. Dan pada angket no. 2 menanyakan tentang pendapat mengenai pelatihan ini berguna untuk menyelesaikan permasalahan dari peserta, dan sekitar $89,94 \%$ peserta menjawab sangat membantu. Serta pada angket no. 3 menanyakan tentang pengetahuan analisis statistik merupakan kebutuhan mutlak dalam mendukung pembuatan skripsi peserta, dan peserta menjawab sangat membutuhkan sebanyak 80,31\%. Dengan diadakannya pelatihan ini diharapkan peserta mampu memahami dan menganalisis analisis regresi linier berganda dengan menggunakan software SPSS sebagai salah satu alternatif dalam menyelesaikan permasalahan skripsi. Hasil untuk angket no 4 yang menanyakan bahwa apakah pelatihan ini efektif? Hampir sekitar $78 \%$ menjawab sangat efektif namun sekitar $22 \%$ yang menyatakan kurang efektif. Dan angket yang no 5 menanakan tentang waktu (durasi) pelatihan, dimana sebagian besar hampir $80 \%$ peserta menyatakan bahwa lama pelatihan adalah kurang. Sehingga dari sebagian besar peserta memberikan masukan untuk melakukan pelatihan lanjutan seperti yang telah disebutkan diatas.

\section{SIMPULAN}

Dari pelatihan diatas, dapat diambil kesimpulan bahwa analisis statistik bagi mahasiswa universitas wiraraja sangatlah membantu mereka dalam menyelesaikan skripsinya. Sehingga dengan diadakannya pelatihan analisis statistika regresi linier berganda ini mampu menjadi salah satu alternatif untuk menjawab beberapa permasalahan mahasiswa dalam menyelesaikan skripsinya. Dalam pelaksanaan pelatihan tersebut sudah memenuhi target kesuksesan bedasarkan dari hasil kriteria evaluasi dengan menggunakan soal dan juga adanya respon positif dari peserta melalui angket yang diminta untuk diisikan setelah pelatihan berakhir. Dan untuk kedepannya pelatihan analisis statistik akan ditambahkan variasinya seperti penggunaan software amos dan eviews supaya mahasiswa memiliki pengetahuan yang lebih dalam menyelesaikan permasalahan skripsinya.

\section{DAFTAR RUJUKAN}

Basuki, A.T. \& Prawoto, N. 2016. Analisis Regresi Dalam Pelatihan Ekonomi \& Bisnis. Jakarta : PT. Raja Grafindo Persada.

Sujarweni, V.W. 2015. SPSS Untuk Pelatihan. Yogyakarta : Pustaka Baru Press. 